\title{
IMPROVING CONCEPTUAL COST ESTIMATING PERFORMANCE PADA PERHITUNGAN HARGA SATUAN TERTINGGI BANGUNAN GEDUNG DI SUMATERA BARAT
}

\author{
Nasril $^{1}$ dan Dwifitra Y.Jumas ${ }^{2}$
}

\begin{abstract}
ABSTRAK
Harga Satuan Tertinggi Bangunan Negara (HST-BGN) yang diatur dalam Peraturan Pemerintah PU 45/PRT/M/2007 merupakan suatu contoh pengunaan metode conceptual estimasi dalam acuan penentuan anggaran. Pedoman tersebut secara teknis berisi bagaimana menghitung estimasi biaya awal konstruksi bangunan gedung serta rumah negara melalui parameter-parameter seperti lokasi, kelas bangunan, luas lantai dan jumlah lantai. Kenyataannya, setiap Pemerintah Daerah Tingkat II menggunakan formula yang seragam dalam bentuk aplikasi spreedsheet untuk mengestimasi biaya konstruksi bangunan gedung di wilayah masing-masing. Kelemahan dari formula ini adalah tidak diakomodasinya perbedaan yang timbul dari parameter-parameter tersebut. Dalam penelitian tahap I, telah ditunjukan bahwa lokasi dan waktu mempengaruhi biaya konstruksi bangunan negara tersebut, terutama yang terkait dengan komponen sumber daya berupa material dan tenaga kerja. Selanjutnya dalam penelitian ini juga perlu ditunjukan suatu conceptual estimasi model yang melibat dua factor lain tersebut yaitu luas lantai dan jumlah lantai yang nantinya akan meningkatkan efisiensi atau performance dari proses biaya conceptual estimasi .
\end{abstract}

Kata kunci : harga satuan, conceptual cost estimating, bangunan gedung.

\section{PENDAHULUAN}

Conceptual cost estimate adalah salah satu masukan fundamental dalam initial decision-making processes untuk proyek-proyek konstruksi. Menurut Trost dan Oberlender (2002) conceptual estimasi menjadi suatu hal yang kritis karena pada tahap ini terdapat proses pengambilan keputusan untuk proyek-proyek konstruksi terutama untuk menentukan apakah proyek akan lanjut atau tidak.Menurut Stephen D. Schuettedan Roger W. Liska (1998) estimasitahapkonseptualadalah "suatu proses yang tidakpasti, karenaperhitunganberdasakansejumlahbesarpenilaian, pengalaman, kurangtersediainformasisertaadanyaketidakpastianselamatahapkonseptual".

Di dalam proyek pemerintah, pengunaan Harga Satuan Tertinggi Bangunan Gedung Negara (HSTBGN) yang di atur dalam Peraturan Menteri Pekerjaan Umum Nomor; 45/PRT/M/2007 merupakan suatu contoh pengunaan metode conceptual estimasi dalam acuan penentuan anggaran. Acuan berguna sebagai syarat-syarat pembangunan proyek gedung negara dengan dana APBN dan bersama dengan peraturan daerah (tingkat 1 maupun II) untuk pembangunan proyek dengan dana APBD. Dalam acuan tersebut, penyusunan pembiayaan gedung negara didasarkan pada standar harga tertinggi per m2 (HST) bangunan gedung negara yang berlaku diwilayah tersebut. Artinya,

\footnotetext{
${ }^{l}$ Staf Pengajar Jurusan Arsitektur Fakultas Teknik Sipil dan Perencanaan Universitas Bung Hatta, nasril.sikumbang@yahoo.com

${ }^{2}$ Staf Pengajar Jurusan Quantity Surveying Fakultas Teknik Sipil dan Perencanaan Univ. Bung Hatta, dwifitraj@yahoo.com
} 
nilai estimasi tidak boleh melebihi dari harga satuan yang di tetapkan oleh pemerintah kabupaten/kota karena nilai harga ini merupakan nilai maksimum dalam estimasi biaya penggangaran untuk bangunan gedung pemerintah.

Bagaimanapun juga, perhitungan conceptual estimasi dengan pengunaan metoda diatas masih mempunyai banyak permasalahan dan pembatasan (restrictions). Permasalahan diatas dapat dikelompokan dalam beberapa pertanyaan yaitu:

1. Apakah perhitungan HST-BGN telah mewakili perbedaan lokasi dan waktu yang diterapkan oleh masing-masing daerah?

2. Bagaimana dengan komponen biaya untuk upah, material dan peralatan yang juga sangat dipengaruhi oleh lokasi dan waktu?

3. Apakah semakin besar kuantitas dan semakin baik kwalitasnya menyebabkan harga komponen semakin mahal, sehingga bobot biayanya akan menjadi lebih besar

4. Apakah faktor lokasi, bentuk dan desain bangunan bisa menyebabkan variasi angka kuantitas komponen dominan dan tentu juga akan menyesuaikan dengan premis awal tentang penentapan HST berdasarkan pada wilayah (lokasi)

5. Apakahparameter untuk Rasio Fasilitas Gedung (RFG) dapat juga mempengaruhi perhitungandari conceptual estimasi.

\section{KWALITAS DARI CONCEPTUAL ESTIMASI}

Bagi pengambil keputusan, kwalitas dari perkiraan estimasi konseptual mencakup keakuratan dan keandalan dalam memperkirakan cost sebuah proyek. Estimasi yang dilakukan pada tahap ini dihadapkan pada suatu kondisi dimana seorang estimator menghitung pendekatan nilai dari informasi (petunjuk) umum tentang sebuah proyek yang akan diselesaikan nantinya.

Kwalitas dan kwantitas dari petunjuk umum yang kita peroleh akan mempengaruhi kemampuan dari estimator untuk memperediksi cost dari suatu proyek yang akan dilakukan. Menurut serpell (2002), ada beberapa faktor yang akan mempengaruhi keakuratan dan kereliabilitasan dari conceptual cost estimasi, diantaranya yaitu;

Tabel 1: Faktor-faktor yang mempengaruhi keakuratan dan reabilitas dari estimasi conceptual

\begin{tabular}{|l|l|l|l|l|}
\hline cope & Information & Uncertainty & Estimator & Procedure \\
\hline Quantities & Processing & Technology & Talent,skill & Mistakes \\
\hline Definition & Sought & Project & Experience & Time available \\
\hline Design Approach & Availability & Environmental & Efford applied & Measurement \\
\hline State of design & Validity & Productivity & Expertise & \\
\hline Completeness & Completeness & Market & Judgment & \\
\hline Detail & Relevance & Construction & Knowledge & \\
\hline Information & & Project nature & Common sense & \\
\hline Quality & & & Team ability & \\
\hline Consistency & & & & \\
\hline Continuity & & & & \\
\hline Project nature & & & & \\
\hline Project & & & & \\
\hline Technology & & & & \\
\hline
\end{tabular}

Faktor-faktor yang akan menentukan keakuratan dan realibitas dari estimasi conceptual dikelompokan dalam 5 kategori utama yaitu; scope quality,information quality, uncertaintly level, estimator performance and quality of the estimating procedure. Secara umum, masing-masing kategori diatas akan saling berlawanan dalam mempengaruhi perhitungan estimasi conceptual. 
Artinya, keterbatasan dan ketidaktentuan definisi dan informasi proyek serta kurang berpengalamnya seorang estimator akan menyumbangkan kesalahan dalam perhitungan.

Disatu sisi, perkembangan dari informasi teknologi akan memberikan mamfaat yang sangat besar untuk perhitungan estimasi conceptual selanjutnya seperti; perkembangan design. Menurut O'Connor and Yang (2004), teknologi (salah satu faktor dari uncertainty) sangat menentukan dalam mengukur cost suatu proyek seperti digambarkan dalam bagan di bawah ini;

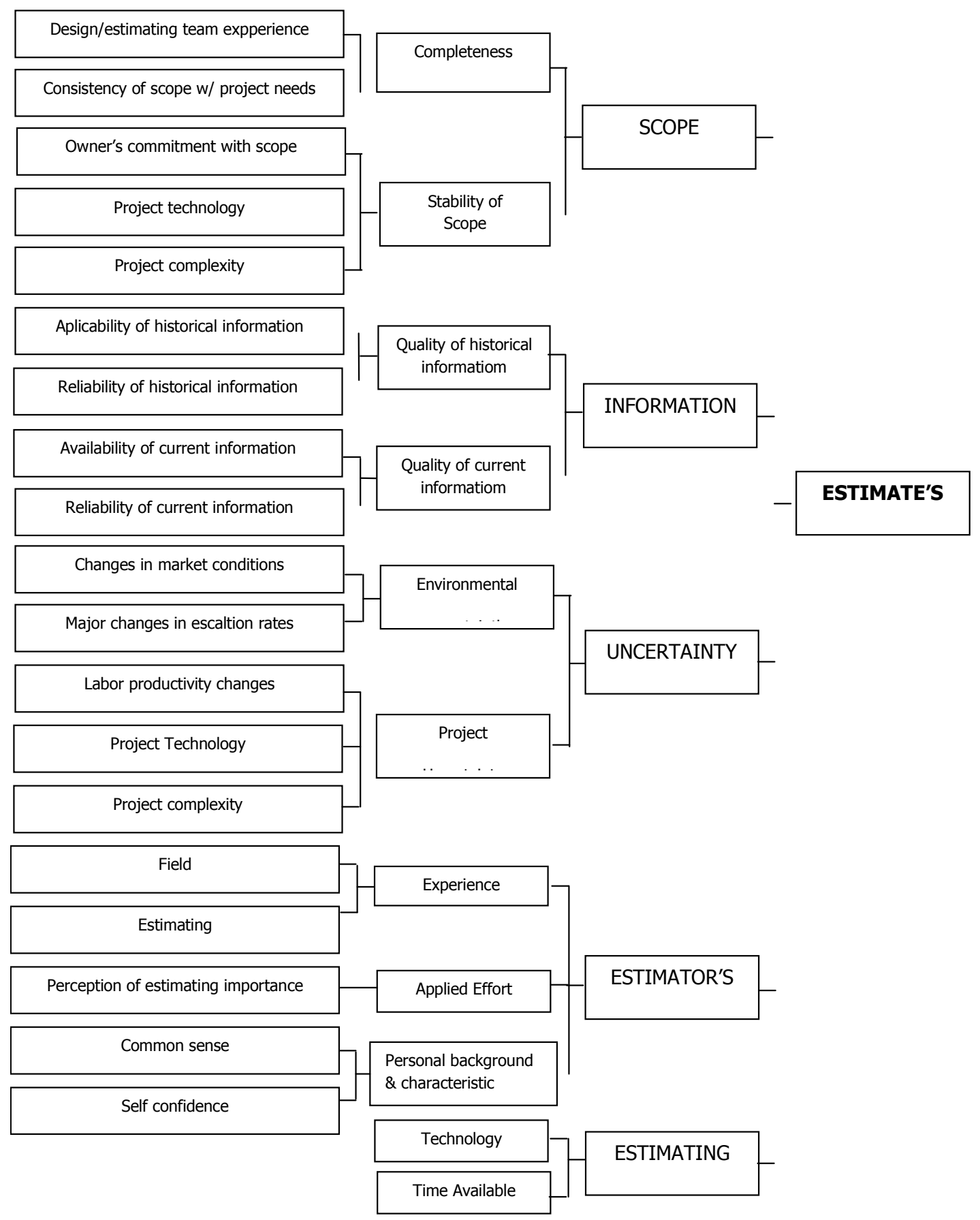

Gambar 1: Faktor yang mempengaruhi estimasi conceptual

\section{KEAKURATAN CONCEPTUAL COST ESTIMASI}


Estimasi biaya awal proyek merupakan salah satu tahapan yang paling penting dalam manajemen proyek konstruksi. Berhasil atau tidaknya sebuah proyek konstruksi sangat tergantung pada keakurasian estimasi yang dilakukan sepanjang proyek mulai dari konseptual sampai estimasi kelayakan dan estimasi detail atau bid estimates. Menurut Trost dan Oberlender (2002) estimasi awal menjadi suatu hal yang kritis karena pada tahap ini terdapat proses pengambilan keputusan untuk proyek-proyek konstruksi terutama untuk menentukan apakah proyek akan berlanjut terus atau tidak. Karenanya kualitas manajemen proyek sangat ditentukan oleh tingkat akurasi estimasi biaya konstruksi Adeli dan $\mathrm{Wu}$ (1998). Estimasi yang tidak akurat tidak hanya mengakibatkan hilangnya kesempatan, tetapi juga menyebabkan upaya pengembangan yang terbuang percuma dan hasil yang lebih rendah dari yang diharapkan Oberlender dan Trost (2001).

Ada dua metode dasar dalam memperdiksikan keakuratan conseptual cost estimasi yaitu;

1) Data-based methods yaitu dengan mengunakan historical data dan quantitative models. Biasanya pendekatan ini digunakan pada situasi atau keadaaanyan proyek yang menyerupai.

2) Judgmental-based method yaitu dengan mengunakan pendapat dan pengalaman seseorang yang ahli dan terbiasa dalam menghitung anggaran biaya suatu proyek. Biasanya para ahli menghitung faktor-faktor apa saja yang mempengaruhi nilai estimasi dengan mengunakan qualitative model

Seperti yang dijelaskan sebelumnya, conceptual cost estimasi dapat digunakan sebagai studi kelayakan, alternatif disain yang mungkin, dan pemilihan disain yang optimal untuk sebuah proyek. Untukmetode Data-based method, banyakcarametode perhitunganyang dapat digunakan dalam menghitung conceptualcost estimasi ini seperti estimasi biaya elemental atau parameter, luas lantai seperti yang diatur dalam Keputusan Menteri Permukiman dan Prasarana Wilayah Nomor: 332/KPTS/M/2002. Hal yang paling terpenting adalah conceptual cost estimasi haruslah akurat, mudah, dan tidak mahal dalam pengunaannya.

Menurut Barrie dan Paulson, (1992) keakuratan estimasi biaya konseptual tergantung pada keahlian dan pengalaman estimator dalam menganalisa rencana proyek yang minim akan informasi dan data. Pengambilan keputusan di tahap awal suatu proyek konstruksi memiliki pengaruh yang besar terhadap kinerja proyek selanjutnya. Tingkat akurasi dalam estimasi biaya merupakan hal yang penting terutama pada tahap awal estimasi. Tingkat akurasi merupakan suatu tingkatan dari pengukuran atau perhitungan yang bervariasi terhadap nilai aktual yang terjadi. Akurasi dari suatu estimasi merupakan suatu indikasi dari tingkatan dari perkiraan biaya terhadap realisasi biaya proyek yang dikeluarkan pada saat proyek selesai (Dysert, 2005).

\section{PERHITUNGAN HST-BGN}

Harga Satuan Tertinggi Bangunan Gedung Negara (HST-BGN) merupakan salah satu metoda estimasi conceptual yang digunakan pemerintah yang diatur dalam Permen PU 45/PRT/M/2007 tentang Pedoman Teknis Pembangunan Gedung Negara. Pada peraturan ini hanya dikenal 3 (tiga) jenis gedung/rumah negara, yaitu bangunan sederhana, bangunan tidak sederhana, dan bangunan khusus.

Menurut Permen ini, "bangunan negara adalah bangunan gedung untuk keperluan dinas yang menjadi/akan menjadi kekayaan milik negara seperti; gedung kantor, gedung sekolah,gedung rumah sakit, gudang, dan rumah negara, dan diadakan dengan sumber pembiayaan yang berasal dari dana APBN, dan/ atau perolehan lainnya yang sah".

Dalam acuan tersebut, penyusunan pembiayaan bangunan gedung negara didasarkan pada standar harga tertinggi per m2 (HST) bangunan gedung yang berlaku di wilayah tersebut. Dengan adanya 
standard harga satuan tertinggi ini, maka menganggarkan biaya konstruksi gedung, nilai estimasinya tidak boleh melebihi dari harga satuan yang telah ditetapkan oleh pemerintah kabupaten/kota, karena nilai harga ini merupakan nilai maksimum dalam estimasi biaya penganggaran untuk bangunangedung pemerintah. Selain menjadi acuan dalam estimasi sebagai nilai maksimum yang dibolehkan dalam penganggaran, HST ini dapat juga bermamfaat sebagai acuan dalam beberapa hal, yaitu: sebagai biaya konstruksi bangunan gedung negara tidak dengan sengaja di-mark-up proyek, dan juga sebagai standar kwalitas bangunan gedung yang dapat dipenuhi oleh pemerintah. Maka dalam manfaat ini, HST konsekuensinya akan dijadikan alat untuk mengendalikan dan proses audit kegiatan pembangunan gedung negara.

Dalam prakteknya, HST menjadi sangat penting dan selalu di jadikan acuan di kabupaten dan kota, baik oleh pemerintah maupun oleh praktisi konstruksi. Standart HST pembangunan gedung negara ditetapkan secara berkala di setiap kabupaten/kota oleh Bupati/Wali kota setempat. Standar HST ditetapkan untuk biaya pelaksanaan konstruksi fisik per-m2 pembangunan bangunan gedung negara dan diberlakukan sesuai dengan klasifikasi, lokasi, dan tahun pembangunannya.Komponen biaya yang dihitung dalam Permen ini terdiri atas;

1. Biaya Konstruksi Fisik

2. Biaya Manajemen Konstruksi

3. Biaya perencanaan teknis konstruksi

4. Biaya pengawasan konstruksi

5. Biaya pengelolaan kegiatan

Dalam penenlitian ini, estimasi conceptual yang dihitung khusus dalam biaya konstruksi fisik saja. Biaya konstruksi fisik yaitu besarnya biaya yang dapat digunakan untuk membiayai pelaksanaan konstruksi fisik bangunan gedung negara yang dilaksanakan oleh penyedia jasa pelaksanaan secara kontraktual dari hasil pelelangan, atau pemilihan langsung .

\section{Proses Conseptual Estimasi Menurut Kepmen Kimpraswil No. 332/02}

Dalam penetapan HST bangunan gedung negara, diperlukan harga satuan yang di tetapkan oleh pemerintah daerah dimana estimasi dilakukan. Harga satuan ini ditetapkan secara periodik oleh setiap pemerintah daerah. Dalam HST, HST rata-rata bagunan gedung bertingkat adalah didasarkan pada luas bangunan yang akan dibangun dikalikan dengan koefisien/faktor pengali jumlah lantai yang bersangkutan, sebagai berikut;

Tabel 2: Faktor Pengali untuk Bangunan Gedung Bertingkat

\begin{tabular}{|l|l|}
\hline Jumlah Lantai & Harga Satuan per m2 Tertinggi \\
\hline Bangunan 2 lantai & 1,090 standar harga gedung bertingkat \\
Bangunan 3 lantai & 1,120 standar harga gedung bertingkat \\
Bangunan 4 lantai & 1,135 standar harga gedung bertingkat \\
Bangunan 5 lantai & 1,162 standar harga gedung bertingkat \\
Bangunan 6 lantai & 1,197 standar harga gedung bertingkat \\
Bangunan 7 lantai & 1,236 standar harga gedung bertingkat \\
Bangunan 8 lantai & 1,265 standar harga gedung bertingkat \\
\hline
\end{tabular}

Untuk pekerjaan fisik non standar, total biaya pekerjaan non standar maksimum sebesar $150 \%$ dari total biaya standar bangunan gedung negara bersangkutan, yang dalam penyusunan anggarannya, perinciannya antara lain dapat berpedoman pada persentase berikut: 
Tabel 3: Biaya Pekerjaan Non Standar

\begin{tabular}{|l|c|}
\hline Jenis Pekerjaan & Persentase \\
\hline Alat pengkodisian udara & $10-20 \%$ dari X \\
\hline Elevator/excavator & $8-12 \%$ dari X \\
\hline Tata surya (sound systim) & $3-6 \%$ dari X \\
\hline Telepondan PABX & $3-6 \%$ dari X \\
\hline Instalasi IT (informasi dan teknologi) & $6-11 \%$ dari X \\
\hline Elektrikal (termaksud genset) & $7-12 \%$ dari X \\
\hline Sisitim proteksi kebakaran & $7-12 \%$ dari X \\
\hline Sistem penangkal petir khusus & $2-5 \%$ dari X \\
\hline Instalasi pengelolaan air limbah & $2-4 \%$ dari X \\
\hline Interior (termasuk funiture) & $15-25 \%$ dariX \\
\hline Gas pembakaran & $1-2 \%$ dariX \\
\hline Gas Medis & $2-4 \%$ dariX \\
\hline Pencegahan bahaya rayap & $1-3 \%$ dariX \\
\hline Pondasi dalam & $7-12 \%$ dariX \\
\hline Fasilitas penyandang cacat \& kebutuhan lain & $3-8 \%$ dariX \\
\hline Sarana/prasara lingkungan & $3-8 \%$ dariX \\
\hline Basement (per m2) & $120 \%$ dariY \\
\hline
\end{tabular}

Catatan: $X=$ total biaya konstruksi fisik pekerjaan standar $\mathrm{Y}=$ Standar harga satuan tertinggi per $\mathrm{m} 2$

Gambar di bawah ini menerangkan bagaimana proses conseptual estimasi terjadi yang ditetapkan oleh pemerintah daerah menurut Kepmen Kimpraswil No. 332/2002. Hal yang terpenting untuk di cermati pada aturan ini adalah proses untuk mendapatkan total luas lantai (TTL). Adapun detail proses tersebut dapat di jelaskan dalam uraian berikut:

1. Informasi awal yang harus dihimpun dinas/dapartemen terkait adalah jumlah penghuni dan lahan peruntukan bangunan tersebut. Jumlah penghuni dimaksudkan untuk mengetahui luas lantai dinas/dapartemen yang bersangkutan. Koefisien penghuni merupakan luas lantai ratarata yang dibutuhkan setiap penghuni gedung yang menjamin kegiatan penghuni berlangsung dengan baik.

2. Langkah selanjutnya adalah menentukan total luas lantai gedung yang akan dibangun. Sementara itu, informasi luas lantai yang bukan peruntukan tidak dibakukan agar dinas/dapartemen terkait bisa menyesuaikan dengan kebutuhan yang unik untuk setiap gedung. Biasanya luas lantai yang bukan peruntukan ini bedasarkan judgement dari instansi masingmasing

3. Pemda setempat berperan dalam menentukan harga satuan tertinggi (HST) dan besar luas lantai dasar maksimal (LDM) yang boleh dibangun, biasanya dinyatakan dalam KDB (koefisien dasar bangunan). KDB merupakan nilai perbandingan antara luas lantai dasar bangunan terhadap lahan peruntukan. (LP)

4. Komparansi antara lahan yang boleh dibangun dengan total luas lantai menghasilkan kesimpulan suatu bangunan gedung itu bertingkat atau tidak.

5. Dari dua informasi konsepsi biaya tersebut dapat dihitung estimasi biaya bangunan gedung. Gedung bertingkat ditetapkan koefisien/faktor penggali untuk masing-masing tingkat, seperti tabel berikut. 


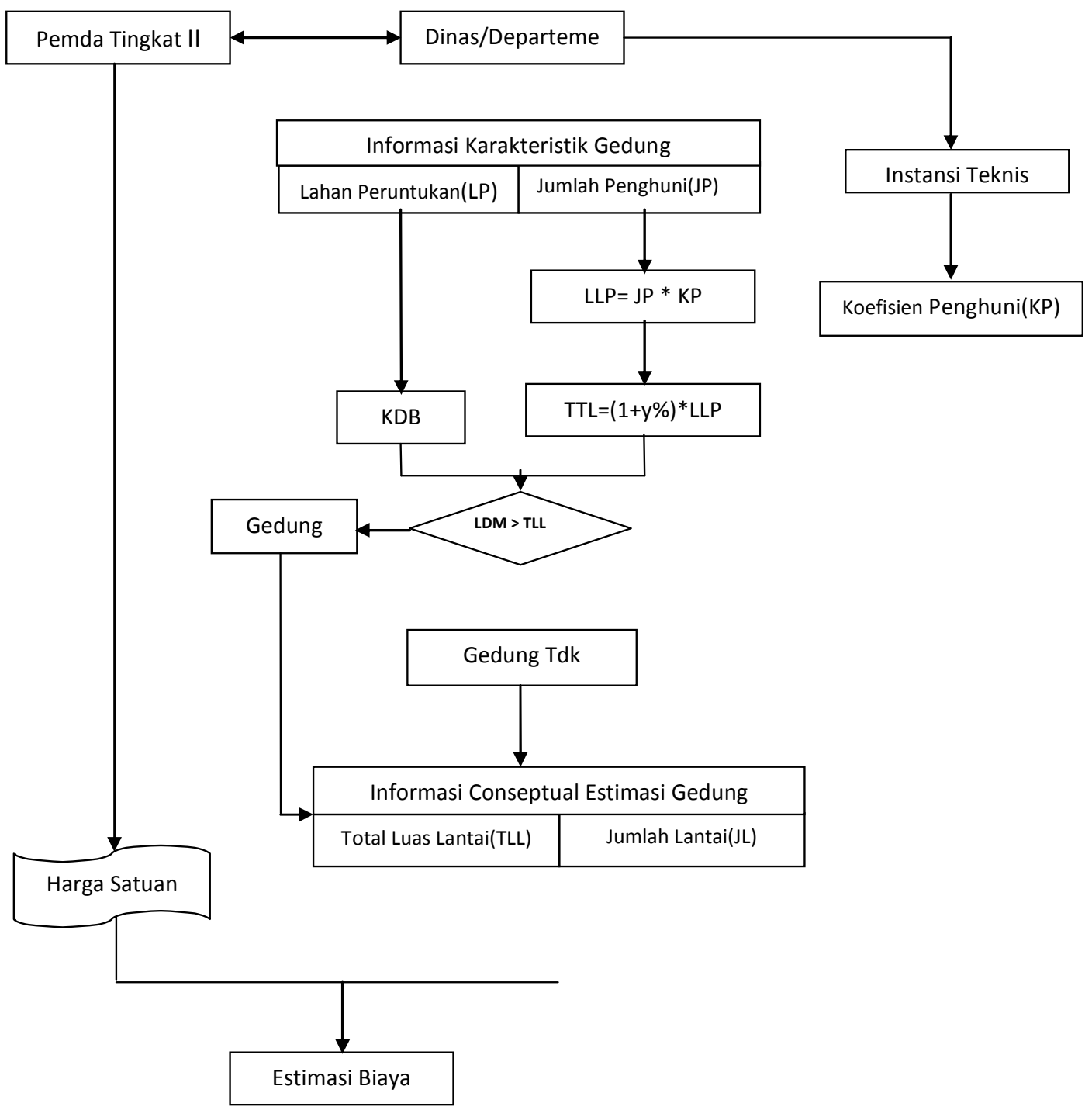

Gambar 3: Proses Conseptual Estimasi Menurut Kepmen Kimpraswill (Abduh, 2006)

\section{PERHITUNGAN PENGEMBANGAN MODEL HST BGN DI SUMBAR}

Sebuahpenelitiantelahdilakukandengan 26 data bangunangedungsederhana 1 lantaimilikpemerintah yang berfungsi sebagai gedung pendidikan, perkantoran, dan layanan kesehatan yang berada pada wilayah Sumatera Barat yaitu kota Padang, Pariaman, Batusangkar dan Pesisir Selatan.

Dari 26 dokumen kontrak yang berhasil dikumpulkan, hanya 20 dokumen yang memenuhi 3 syarat yang telah ditetapkan yaitu:

1. Rencana Anggaran Biaya (RAB)

2. Analisa Harga Satuan (AHS) pekerjaan yang lengkap untuk setiap pekerjaan yang tertera dalam RAB 
3. Gambar denah bangunan untuk menentukan luas bangunan

Syarat yang paling sulit untuk dipenuhi adalah syarat yang kedua yakni; banyak dokumen kontrak yang tidak memiliki Analisa Harga Satuan (AHS) yang lengkap.

Dari pengolahan data secara statistic mengunakan unit dan parametric method didapatkan beberapa kesimpulan. Untuk presentase bobot biaya komponen material, upah dan alat untuk masing-masing bangunan berdasarkan lokasi dapat dilihat pada tabel dibawah ini

Table 3 Rekapitulasi \% Bobot Biaya Komponen Matrial, Upah dan Alat

\begin{tabular}{|l|l|l|l|l|}
\hline \multirow{2}{*}{ NO } & \multirow{2}{*}{ LOKASI SURVEY } & \multicolumn{3}{|l|}{$\%$ BOBOT BIAYA KOMPONEN } \\
\cline { 3 - 5 } & & MATERIAL & UPAH & ALAT \\
\hline 1 & PADANG & $71,56 \%$ & $26,43 \%$ & $2,01 \%$ \\
\hline 2 & PESISIR SELATAN & $70,01 \%$ & 30,56 & $0,57 \%$ \\
\hline 3 & PARIAMAN & $69,89 \%$ & 29,42 & $0,69 \%$ \\
\hline 4 & BATUSANGKAR & $72,81 \%$ & $25,30 \%$ & $1,89 \%$ \\
\hline
\end{tabular}

Berdasarkan tabel 3, komponen material dan upah memiliki bobot rata-rata yang paling, yaitu komulatif bobot keduanya pada masing-masing lokasi > 90\% dari biaya total pelaksanaan pekerjaan standar. Oleh karena itu, komponen material dan upah pekerja akan ditetapkan sebagai komponen dominan.

Komponen material dan upah yang dominan adalah jenis material dan upah yang memiliki bobot biaya paling besar dalam pembangunan gedung. Untuk menentukan jenis material sebagai komponen dominan, maka dilakukan dengan mengakumulasi bobot rata-rata komponen material dan upah secara berurutan dari yang terbesar hingga mencapai bobot komulatif sebesar $80 \%$. Alasan memakai bobot komulatif sebesar $80 \%$ ini sesuai dengan konsep Pareto, yang menyatakan bahwa bobot biaya sebesar $80 \%$ dari komponen dominan sudah mewakili $100 \%$ dari total nilai biaya. Nilai kuantitas komponen material dan upah dominan diperoleh dari perhitungan batas atas estimasi dengan confidence level $90 \%$ dan $95 \%$. Pada perhitungan model HST-BGN ini, bobot komulatif komponen bahan bangunan sebesar $80 \%$ akan dijadikan kembali ke $100 \%$.

Dari hasil pengolahan data selanjutnya, diketahui bahwa setiap bangunan memiliki komponen material dan upah dominan yang berbeda-beda. Hal ini tergantung dari faktor lokasi, kuantitas dan kualitasnya. Semakin besar kuantitas dan semakin baik kualitasnya menyebabkan harga komponen tersebut semakin mahal, sehingga bobot biayanya menjadi lebih besar. Tabel 4.3 berikut menunjukan komponen dominan dan kuantitas masing-masing lokasi:

Tabel 4 Rekapitulasi Komponen Dominan dan Kuantitas

\begin{tabular}{|c|c|c|c|c|c|c|c|c|c|c|}
\hline \multirow[t]{2}{*}{ No } & \multirow[t]{2}{*}{ Komponen } & \multirow[t]{2}{*}{$\begin{array}{l}\text { Sa } \\
\text { tuan }\end{array}$} & \multicolumn{4}{|c|}{$\begin{array}{l}\text { Kuantitas dengan Confidence Level } \\
95 \%\end{array}$} & \multicolumn{4}{|c|}{$\begin{array}{l}\text { Kuantitas dengan Confidence Level } \\
90 \%\end{array}$} \\
\hline & & & $\mathrm{A}$ & B & $\mathrm{C}$ & $\mathrm{D}$ & A & B & $\mathrm{C}$ & $\mathrm{D}$ \\
\hline 1 & Semen & Zak & 26539 & 26159 & 26468 & 25425 & 25040 & 25500 & 26082 & 24926 \\
\hline 2 & Batu bata & Buah & 1101445 & 1012620 & 1100954 & 1013044 & 1084882 & 992988 & 1076650 & 1001544 \\
\hline 3 & $\begin{array}{l}\text { Keramik } \\
\text { lantai }\end{array}$ & M2 & 11479 & 11710 & 11736 & 11610 & 11174 & 11422 & 11531 & 11435 \\
\hline 4 & Pasir & M3 & 0,3410 & 0,3508 & 0,3470 & 0,3019 & 0,3263 & 0,3356 & 0,3425 & 0,3974 \\
\hline 5 & Genteng & Buah & 473896 & 467837 & 420720 & 454159 & 464244 & 454469 & 416753 & 447205 \\
\hline 6 & Besi beton & $\mathrm{Kg}$ & 114172 & 104194 & 113164 & 113164 & 112208 & 102452 & 110973 & 1109973 \\
\hline 7 & Kayu balok & M3 & 0,1396 & 0,1425 & 0,1410 & 0,1447 & 0,1325 & 0,1389 & 0,1395 & 0,1407 \\
\hline 8 & $\begin{array}{l}\text { Kayu } \\
\text { papan }\end{array}$ & M3 & 0,0352 & 0,0364 & 0,0307 & 0,0383 & 0,0327 & 0,0301 & 0,0327 & 0,0376 \\
\hline 9 & Mandor & Hari & 0,4282 & 0,3983 & 0,3893 & 0,4168 & 0,4134 & 0,3882 & 0,3698 & 0,4119 \\
\hline 10 & Kepala & Hari & 0,8485 & 0,7906 & 0,8570 & 0,7955 & 0,8302 & 0,7818 & 0,7906 & 0,8424 \\
\hline
\end{tabular}




\begin{tabular}{|l|l|l|l|l|l|l|l|l|l|l|}
\hline & tukang & & & & & & & & & \\
\hline 11 & Tukang & Hari & 5,1906 & 5,0321 & 5,1612 & 4,9981 & 5,0708 & 4,9553 & 5,0911 & 4,9293 \\
\hline 12 & Pekerja & Hari & 4,6558 & 4,7389 & 4,6718 & 4,4572 & 4,5218 & 4,5030 & 4,7061 & 4,3934 \\
\hline
\end{tabular}

Keterangan, A = Padang; B = Pesisir Selatan; C = Pariaman; D = Batusangkar

Dari Tabel 4 diatas diketahui bahwa komponen material dan upah pada masing-masing lokasi memiliki kuantitas yang tidak sama. Dari sini dapat disimpulkan bahwa faktor lokasi juga mempengaruhi bentuk dan desain bangunan. Perbedaan desain bangunan pada masing-masing lokasi bisa menyebabkan variasi angka kuantitas komponen dominan, hal ini tentunya sesuai dengan premis awal tentang kebutuhan penetapan HST yang berdasarkan pada wilayah.

Uji validasi model HST-BGN dalam penelitian ini, dilakukan dengan cara membandingkan hasil estimasi biaya bangunan gedung pada suatu lokasi dengan Harga Satuan Tertinggi yang dikeluarkan Pemerintah Daerah setempat. Sebagai alat validasi, diambil data biaya bangunan yang telah selesai dibangun, dimana memiliki karakteristik gedung standar pada masing-masing lokasi. Sebelumnya nilai konstruksi bangunan tersebut di konversikan ke tahun pada saat validasi dilakukan dengan mengunakan indeks biaya bangunan gedung. Karena di Indonesia belum ada pihak yang menerbitkan nilai indeks biaya tersebut, maka untuk menyesuaikan biaya bangunan terhadap waktu digunakan angka validasi. Meskipun perlu dicatat bahwa pengujian model dengan angka inflasi umumtidak mewakili biaya bangunan gedung negara, sebab angka inflasi sebenarnya berasal dari Indeks Harga Konsumen (IHK) yang menunjukan perubahan harga paket barang dan jasa yang rata-rata di komsumsi oleh rumah tangga selama satu bulan seperti, bahan makanan, sandang, perumahan, kesehatan, rekreasi, oleah raga, transportasi dan komunikasi.Hasil uji validasi yang mengunakan nilai inflasi tahunan dapat dilihat pada Tabel 5

Hasil uji validasi menunjukan bahwa estimasi dengan nilai inflasi tahunan yang mengunakan HST yang dikeluarkan oleh Pemerintah Daerah cendrung overestimate hingga mencapai $+82 \%$. Sedangkan hasil estimasi berdasarkan model HST-BGN yang dikembangkan cendrung overestimate hingga mencapai $+48 \%$.

Uji validasi model HST-BGN yang dilakukan dengan mengunakan angka inflasi kurang cocok untuk dipakai, karena tidak mewakili komponen bangunan gedung negara. Untuk itu maka model HST-BGN yang dikembangkan akan di uji dengan mengunakan data komponen harga-harga real pada tahun yang bersangkutan. Hasil dari uji validasi yang mengunakan data komponen harga di tahun yang bersangkutan memiliki perbedaan hingga $+25 \% \%$ dari nilai proyek, sedangkan hasil validasi berdasarkan nilai inflasi tahunan memiliki perbedaan hingga $+45 \%$ dari nilai proyek. Hal ini disebabkan karena angka inflasi tahunan memang bukan ditujukan untuk bangunan gedung negara. 
Tabel 5 Hasil validasi dengan Inflasi Tahunan

\begin{tabular}{|c|c|c|c|c|c|c|c|c|}
\hline \multirow[b]{2}{*}{ No } & \multirow[b]{2}{*}{ Proyek } & \multirow[b]{2}{*}{ Thn } & \multirow[b]{2}{*}{ Luas } & \multirow[b]{2}{*}{$\begin{array}{l}\text { Harga } \\
\text { Sebenarnya }\end{array}$} & \multirow[b]{2}{*}{$\begin{array}{l}\text { Normalisai } \\
\text { Biaya }\end{array}$} & \multicolumn{3}{|l|}{ Estimasi Biaya } \\
\hline & & & & & & $\begin{array}{l}\text { Model } \\
\text { Pemerintah }\end{array}$ & $\begin{array}{l}\text { Model HSTBGN } \\
95 \%\end{array}$ & $\begin{array}{l}\text { Model HSTBGN } \\
90 \%\end{array}$ \\
\hline \multirow{3}{*}{1} & \multirow{3}{*}{$\begin{array}{l}\text { Pembangunan } \\
\text { Puskesmas } \\
\text { Lapai } \\
\end{array}$} & \multirow{3}{*}{2009} & \multirow{3}{*}{497,5} & \multirow{3}{*}{1.027 .188 .618} & 1.182 .191 .380 & 1.376 .582 .500 & 1.312 .218 .438 & 1.278 .287 .445 \\
\hline & & & & & Perbedaan & 349.393 .882 & 285.029 .820 & 96.096 .065 \\
\hline & & & & & $\%$ & $45 \%$ & $24 \%$ & $18 \%$ \\
\hline & & & & & & & & \\
\hline \multirow{3}{*}{2} & \multirow{3}{*}{$\begin{array}{l}\text { Pembangunan } \\
\text { Gedung Pend. } \\
\text { Asrama } \\
\text { komplek LPMP }\end{array}$} & \multirow{3}{*}{2004} & \multirow{3}{*}{345,47} & \multirow{3}{*}{343.800 .000} & 592.328 .000 & 955.915 .490 & 816.936 .618 & 797.818 .308 \\
\hline & & & & & Perbedaan & 363.587 .490 & 224.608 .618 & 205.490 .308 \\
\hline & & & & & $\%$ & $68 \%$ & $37 \%$ & $30 \%$ \\
\hline & & & & & & & & \\
\hline \multirow{3}{*}{3} & \multirow{3}{*}{\begin{tabular}{lr}
\multicolumn{2}{l}{ Pembangunan } \\
Kios di \\
Pelabuhan di \\
Samudra bungus \\
\end{tabular}} & \multirow{3}{*}{2006} & \multirow{3}{*}{250} & \multirow{3}{*}{280.513 .241} & 378.692 .875 & 691.750 .000 & 518.812 .500 & 504.977 .500 \\
\hline & & & & & Perbedaan & 313.057125 & 140.119 .625 & 126.284 .625 \\
\hline & & & & & $\%$ & $83 \%$ & $37 \%$ & $34 \%$ \\
\hline & & & & & & & & \\
\hline \multirow{3}{*}{4} & \multirow{3}{*}{$\begin{array}{l}\text { Pembangunan } \\
\text { Rumah Dinas } 1 \\
\text { Unit } 2 \text { Pintu } \\
\text { SDN }\end{array}$} & \multirow{3}{*}{2007} & & & 269.478 .400 & 432.234 .000 & 391.675 .500 & 366.030 .820 \\
\hline & & & 102 & 130.368 .000 & Perbedaan & 162.755 .600 & 122.197 .100 & 96.552 .420 \\
\hline & & & & & $\%$ & $60 \%$ & $45 \%$ & $36 \%$ \\
\hline & & & & & & & & \\
\hline & Pembangunan & & & & 432.567 .867 & 789.048 .850 & 684.286 .637 & 568.705 .660 \\
\hline 5 & Rumah Negara & 2009 & 281,55 & 327.021 .000 & Perbedaan & 356.480 .983 & 251.718 .770 & 136.137 .793 \\
\hline & $\begin{array}{l}2 \text { Unit Kec.IV } \\
\text { Jurai }\end{array}$ & & & & $\%$ & $82 \%$ & $48 \%$ & $32 \%$ \\
\hline & Pembangunan & & & & 1.543 .434 .000 & 1.947 .137 .900 & 1.460 .353 .425 & 1.421 .410 .667 \\
\hline & Gedung & & & & Perbedaan & 503.703 .900 & 498.765 .356 & 401.232 .343 \\
\hline 6 & $\begin{array}{l}\text { Komoditi } \\
\text { Primer } \\
\text { Kampung } \\
\text { Dalam } \\
\end{array}$ & 2007 & 703,7 & 1.069 .180 .000 & $\%$ & $38 \%$ & $20 \%$ & $15 \%$ \\
\hline & Pembangunan & & & & 467.765 .634 & 741.944 .000 & 581.458 .000 & 568.619 .120 \\
\hline 7 & Gedung & 2007 & 232 & 322792634 & Perbedaan & 374.228 .324 & 113.692 .366 & 100.854 .486 \\
\hline & $\begin{array}{l}\text { Poliklinik RSU } \\
\text { Lubuk Sikaping }\end{array}$ & & & & $\%$ & $81 \%$ & $35 \%$ & $24 \%$ \\
\hline & Pembanguna & & & & 3.834 .957 .000 & 5.941 .474 .000 & 4.781 .105 .500 & 4.680 .276 .020 \\
\hline 8 & Kantor Pemda & & 1822 & 2.659 .925 .000 & Perbedaan & 2.106 .517 .000 & 946.148 .500 & 845.319 .020 \\
\hline & Batusangkar & 2007 & & & $\%$ & $65 \%$ & $34 \%$ & $26 \%$ \\
\hline & & & & & & & & \\
\hline & Pembangunan & & & & 3.287 .657 .234 & 4.965 .550 .000 & 3.424 .162 .500 & 3.332 .851 .500 \\
\hline 9 & Gedung & 2007 & 1650 & 2821794831 & Perbedaan & 1.677 .892 .766 & 365.952 .266 & 123.543 .123 \\
\hline & $\begin{array}{l}\text { Nasional } \\
\text { Batusangkar }\end{array}$ & & & & $\%$ & $51 \%$ & $16 \%$ & $12 \%$ \\
\hline & & & & & & & & \\
\hline & & & & & 776.897 .432 & 1.466 .510 .000 & 1.099 .882 .500 & 1.026 .557 .000 \\
\hline 10 & Pembangunan & 2009 & 530 & 4886.664 .846 & Perbedaan & 689.612 .568 & 322.985 .068 & 249.659 .568 \\
\hline & & & & & $\%$ & $80 \%$ & $42 \%$ & $32 \%$ \\
\hline & & & & & & & & \\
\hline
\end{tabular}

\section{KESIMPULAN DAN SARAN}

1. Model estimasi HST-BGN yang dikembangkan dapat digunakan dengan cukup akurat dalam mengestimasi biaya konstruksi bangunan gedung pada tahap awal, seperti studi kelayakan dan penganggaran 
2. Model ini memiliki akurasi yang cukup baik dari model yang selama ini dipakai oleh pemerintah

3. Model HST-BGN ini dapat mengefisiensikan biaya dalam estimasi penggangaran hingga 50\% dari model yang dipakai pemerintah.

4. Untuk penelitian selanjutnya juga perlu dipertimbangkan parameter lainnya yang mempengaruhi perhitungan conceptual estimasi seperti rasio fasilitas gedung dan dengan metide perhitungan lainnya

\section{DAFTAR KEPUSTAKAAN}

Departemen Pemukiman dan Prasarana Wilayah (2007). Peraturan Menteri No 45/PRT/M/2007 tentang Pedoman Teknis Pembangunan Bangunan Gedung Negara

Dinas Tata Ruang dan Pemukiman Propinsi Sumatera Barat. Analisa Harga Satuan Pekerjaan Kota Padang Tahun Anggaran 2010 Triwulan Juli-September

Dinas Tata Ruang dan Pemukiman Propinsi Sumatera Barat. Analisa Harga Satuan Pekerjaan Kota Pariaman Tahun Anggaran 2010 Triwulan Juli-September

Dinas Tata Ruang dan Pemukiman Propinsi Sumatera Barat. Analisa Harga Satuan Pekerjaan Kota Pesisir Selatan Tahun Anggaran 2010 Triwulan Juli-September

Dinas Tata Ruang dan Pemukiman Propinsi Sumatera Barat. Analisa Harga Satuan Pekerjaan Kota Batusangkar Tahun Anggaran 2010 Triwulan Juli-September

Fortune, C., dan Lees, M., early Cost Advice for Clients, Royal Instituion of Chartered Surveyor, London, 1994

HS.Ang, Alfredo \& Tang, Wilson \& Hariandja, Binsar (1975). Pengembangan Konsep-Konsep Probalitas dalam Perencanaan dan Perancangan Rekayasa Erlangga, Jakarta

O'Conner J and L Yang (2004). Project Performance Versus Use of Technologies at Project and Phase Level. Journal of Construction Engineering and Management. 322-329

Rush, C.,R.Boy (2001).Expert Judgement in Cost Estimating Modelling the Reasoning Process. Concurent Engineering Research and Applications. 271-284

Scheutte, S.D., and Liska, R.W., Building Construction Estimating, MC Graw Hill, Singapura 1994 Spector (1999). Parametric Estimating Handbook. http://www.ispa-cost. org/PEIWeb/newbook.htm Trost, S.M. and Oberlender, G.D. (2002). Predicting Accuracy of Early Cost

Estimates Using Factor Analysis and Multivariate Regression, J. Construction Engineering and Management, Vol. 129, No. 1, 198-204.

Wijiastuti, Dwiretno (2006). Pengembangan Model Indeks Biaya untuk Estimasi Biaya Konseptual Bangunan Gedung, Tesis Program Magister, ITB 